\title{
Learning for Life: From Compulsory Vaccination to Vaccination Education in 19th and 20th Century Germany
}

\author{
Malte Thießen (LWL-Institut für westfälische Regionalgeschichte)
}

\begin{abstract}
:
In my essay I will trace the connections between vaccination and education using examples of German history from the 19th and 20th centuries. Germany did not take a special path (Sonderweg), as one might have assumed given its historical development and the five different political systems. Rather, it is a typical example of the European political approach to vaccination. These form the background for my initial questions: what was the relationship between social order and vaccination programmes and what role did schools and educational models play in vaccination programmes? It is demonstrated that schools played a major role in both in the enforcement of compulsory vaccination and the establishment of vaccination education.
\end{abstract}

Keywords:

compulsory vaccination; Europe; history; social order; vaccination education

Immunity is a social matter: vaccinations never aim solely to protect the individual, instead they protect society as a whole. Vaccinations are also used as a tool to completely eradicate infectious diseases. Physicians consider this to be the concept of "herd immunity". With a vaccination rate of between 90 and 95 percent, herd immunity is achieved, causing infectious diseases to disappear forever. Herd immunity also protects those who cannot be vaccinated, such as very young or very old people, as well as those with underlying health conditions for whom vaccination can pose a risk.

Therefore, the immunity of the individual is a contribution to the health of society and vice versa. Vaccinations link the well-being of the individual with the well-being of the general public. This is not only true in terms of herd immunity. The question of the potential side effects of vaccination not only affect the individual, but the general public too. Side effects raise questions of principle: which is more serious, the risk to the individual or the public? Are state authorities allowed to force the individual to be vaccinated in order to ensure the general good? These questions alone make it clear that vaccination encompasses fundamental issues: it concerns the relationship between the individual and society, the rights and duties of the state, the importance of solidarity and the question of how societies wish to live in the future. Against this background, it is no coincidence that immunity is not only a social matter, but also an educational one. On the one hand, the success of vaccination programmes is linked to the institution of the school. Even the earliest vaccination campaigns in the 19th century required school buildings and teachers (Tolley, 2019). On the other hand, vaccination became proof of the correct education of "modern" and reliable citizens.

In my essay I will trace the connections between vaccination and education using examples of German history from the 19th and 20th centuries. This period is particularly interesting, enabling the development of vaccination in five different political systems to be traced: in the German Empire from the 1870s until the end of World War I, in the first democratic republic of Germany, namely the Weimar Republic between 1918 and 1933, in the "Third Reich" and after 1945 in the socialist GDR and the democratic Federal Republic. As Sauerteig (1995) has shown for campaigns against venereal diseases in England and Germany, Germany did not take a special path (Sonderweg), as one might have assumed given its historical development and the five different political systems. Rather, it is a typical example of the European political approach to vaccination. For this reason, references between German health policy and that of other countries, especially England, will play a role in the following. Although I cannot investigate all systems, they form the background for my initial questions: what was the relationship between social order and vaccination programmes and what role did schools and educational models play in vaccination programmes? To answer these questions, I concentrate on the fundamental change in vaccination, the change from compulsory vaccination to the concept of "vaccination education", which replaced compulsory measures from the 1930s onwards in Germany. Schools played a major role in both phases, both in the enforcement of compulsory vaccination and the establishment of vaccination education. 
Edward Jenner's vaccination against smallpox gave the starting signal for vaccination campaigns throughout Europe and beyond, at the end of the 18th century. At that time, smallpox was one of the most contagious and deadly diseases. The foundation of the German Reich in 1871 presented the Germans with the task of developing a national vaccination programme against smallpox for the first time (Huerkamp, 1985). In 1874, during several sessions, the members of the German Parliament (Reichstag) discussed the introduction of the "Imperial Vaccination Act" (Reichsimpfgesetz) requiring all children to be vaccinated against smallpox at the age of one and 12. A central reference point for discussions in the Reichstag was England as the birthplace of modern vaccination programmes. There, a state vaccination was first introduced as a nationwide compulsory measure: since the $1850 \mathrm{~s}$, every child had to be vaccinated against smallpox after birth. The "Vaccination Act" ennobled England as the "motherland of vaccination", as German physicians called it in the 19th century. Since then, Germany looked longingly to the island where the dream of modernity seemed to have come true: the rational planning of social health conditions.

Schools played a central role in the development of the Vaccination Act for several reasons. Firstly, schools solved the constant problem of space. During the 19th century, smallpox vaccinations in Germany were often carried out in restaurants and even pubs. As hygiene awareness grew among the German public, such places brought into question the cleanliness and safety of vaccinations. School buildings symbolized state standards for the proper implementation of vaccination programmes. In addition, schools made it easier to organize mass vaccination. With the introduction of the Vaccination Act, school classes were vaccinated together in the gymnasiums, auditoriums and assembly halls of schools on annual vaccination dates.

Another factor underlying the importance of schools in this process, was the meaning of vaccination as a state of education in the population. Already in the Reichstag debates of 1874, the inadequate "cultural state" of the Germans had been used as an argument for compulsory vaccination by members of parliament, such as August Zinn from the Progress Party (Fortschrittspartei) (Deutscher Reichstag, 1874, p. 110). Immunity thus became the goal of the reliable and dutiful citizen. One textbook for schools even described the vaccination against smallpox as the "physical education of the cultural man” (Laurenz Sonderegger, 1930).

However, the most important reason was compulsory schooling. Wilhelm Löwe of the Progress Party summed up this importance of schools in the implementation process of vaccination in a Reichstag debate in 1874 , as follows:

But we have an interest in vaccinating children at an age when they are still required to attend school, avoiding a situation in which some unruly father or guardian can say:
'I'd rather take my child out of school completely, it will soon be time to finish anyway, then the matter is over'. (Deutscher Reichstag, 1874, p. 104)

Compulsory schooling thus supported compulsory vaccination and ensured that state actors had access to public health. The institutionalization of vaccination in schools also signalled who should henceforth bear responsibility for the health of children: the state, not the family.

Since the 1870 s, vaccinations literally opened the door to school buildings and vice versa: when enrolled in a school, a vaccination certificate had to be presented before a child was permitted to attend secondary school. In addition, the authority of directors and teachers was used to increase the pressure on parents. In this respect, the implementation of vaccination programmes in schools was also important, so as not to indulge anti-vaccinationists, as the Prussian Deputation for Medicine declared in 1904:

The renunciation of the right to reject unvaccinated children from admission to a higher educational institution would deprive the administration of one of the most effective means of coercion in the field of protective smallpox vaccination and would be seen by opponents of the vaccination as an official concession. ${ }^{1}$

\section{$* * *$}

The role of schools in enforcing compulsory vaccination programmes was met with criticism at the turn of the century, not just in Germany (Colgrove, 2006; Durbach, 2005; Walloch, 2007). Vaccinations as a "mass processing" exercise in the gymnasiums and auditoriums of schools was widely criticized. Moritz Pauli of the German Imperial Party (Deutsche Reichspartei), described the problems of mass vaccination in a debate in the Reichstag in 1896 from his own experience:

As a teacher, I was a supervisor in a vaccination session, 60 boys from our school - including a few more additional children - were vaccinated; this session lasted just over an hour. Well, gentlemen, how is a doctor capable of assessing a child's state of health in less than one minute before administering a vaccination? (Deutscher Reichstag, 1896, p. 2218)

During the Weimar Republic, however, the criticism was increasingly vociferous. This criticism affected schools in particular, which as places of mass vaccination, were increasingly being blamed for side effects or improper vaccinations. Even the teachers were now a problem. Since the 1920s, physicians had observed with concern that many teachers did not take vaccinations very seriously. In the mid1920s for example, the Hamburg police department complained to the school department about an increasing lack of discipline. The police observed more and more frequently that groups of schoolchildren and even entire school classes chose not to be vaccinated. Outraged, one policeman described a teacher's explanation for the absence of his pupils 
that the latter had had to attend "a Punch and Judy show"2 instead of the annual vaccination appointment.

The declining interest of teachers in smallpox vaccination programmes reflected a general trend. Smallpox was no longer a major issue in Germany in the 1920s. Since the introduction of the Vaccination Act, the death toll had fallen to nearly zero. With the dissipation of the fear of smallpox, interest in vaccinations also declined. The success of vaccinations ultimately led to a drop in the vaccination ratea typical example of the precautionary paradox (Woollacott, 1998). Another problem in relation to herd immunity was the effect of the greatest vaccination disaster that shook the whole of Germany in 1930. Seventy-seven children died when a vaccination against tuberculosis was administered incorrectly in the city of Lubeck. The "Lubeck disaster" made headlines in newspapers and raised the question of introducing a "conscience clause" that was established in England already in 1907.

Interestingly, England remained the reference even in the "Third Reich". A bill from the Ministry of the Interior in 1934 proposed an amendment to the vaccination law "by inserting a conscience clause based on the English model" (Beratung, 1934). It is true that by then the English reference also met occasional rejection. Representatives of the Robert Koch Institute, for example, spoke of the "conscience clause" as a "dusty prop of Manchesterian parliamentarianism" (Beratung, 1934). In 1934, however, there was a general agreement that the compulsory vaccination had to be relaxed. "If the compulsory vaccination remains in place", the Reich Ministry of the Interior declared, "the German people will doubt that National Socialist principles are decisive in medical policy." (Beratung, 1934)

Against this background, a change of course in vaccination programmes began in the 1930s. The compulsory vaccination against smallpox was increasingly flanked by advertising measures and educational work. Forced vaccinations against the will of the child and parents, which were still common in the 1920 s, were no longer carried out after 1930. Even the link between compulsory school attendance and compulsory vaccination no longer applied. Since 1936, proof of a smallpox vaccination was no longer a requirement to attend secondary schools. ${ }^{3}$

This change of course was particularly evident in relation to the vaccination against diphtheria. The diphtheria vaccination was tested in some parts of Germany in the mid1930s and introduced nationwide in the early 1940s. Compulsory vaccination was no longer under discussion. Instead, health authorities relied on voluntariness and persuasion, especially in schools. Vaccination now became a school subject with the help of various media. In addition to educational films, brochures, books and lectures, "letters to parents" (Elternbriefe) were also used. In German lessons, such letters were given to the pupils for dictation. Afterwards, pupils brought these letters home to their parents. "Dear mother, dear father!" parents could read in the letter,

The worst disease for children is diphtheria. Many thousands of children my age died of it this year. Millions of children in Germany and also in other countries have already been vaccinated. Don't you want to protect me too, dear parents? I beg you to! (Behringwerke, 1941).

The letters to parents are interesting for several reasons. Firstly, they mark the breakthrough of a new vaccination policy. Vaccinations should no longer be prescribed "from above". Advertising was now aimed at awakening needs and stirring up fears. From now on, the "preventive self" (Lengwiler \& Madarász, 2010) was addressed, which focused on taking health protection into one's own hands. Against this background, a veritable flood of images became comprehensible, which have inundated German pupils since the end of the 1930s. Images of happy or threatened children in films, slide shows, brochures and books addressed hopes and fears and were intended to increase the popularity of vaccination programmes. One could say the greater the voluntariness, the more clearly the horrors of diphtheria had to be portrayed. The new advertisement also was copied from the West. In an investigation for the Ministry of the Interior in the mid-1930s, Max Gundel referred to vaccination campaigns from the USA, Canada and England as a signpost for new ways of vaccination advertising in Nazi Germany (Gundel, 1936).

The "letters to parents" were also informative from another perspective. Advertising materials like this did not come from the health authorities or ministries, as one would assume with a governmental vaccination programme, but from pharmaceutical companies. Behringwerke in Marburg demonstrated a particularly firm commitment to advertising. The company brought films, brochures, posters, teaching materials and even plays to the stage to teach students the benefits of vaccinations. This change of course from compulsory to voluntary vaccination and to vaccination education was thus based on an economization of the health care system (Hüntelmann, 2011).

This trend continued in the Federal Republic. Pharmaceutical companies continued their advertising campaigns in the "Third Reich" without interruption. In the mid-1950s, for example, teachers were informed in a brochure compiled by Behringwerke that the decree of 1938 had "expressly ordered vaccination as a joint task":

The health leadership (Gesundheitsführung) [...] is of the opinion that it must be made possible to educate and inform every German about his child's and the people's health ("Volksgesundheit") in such a way that no child is spared the protective vaccination. ${ }^{4}$

It would be easy to dismiss such references to the "Gesundheitsführung" and "Volksgesundheit" as a remnant of the Nazi era. However, a glimpse at vaccination 
programmes after 1945 suggests that references to "Volksgesundheit" and even to "Volksgemeinschaft" remained popular for a long time (Thießen, 2017, p. 229). Such continuities in vaccination education between the Nazi era and the Federal Republic were not a problem for physicians. On the contrary, as late as the 1970s, a medical dissertation even celebrated the vaccination programme against diphtheria under National Socialism as a role model of "modern" advertising (Aumiller, 1970, p. 21).

Vaccination education in schools, which was designed by pharmaceutical companies, thus remained a cornerstone of public health after 1945, as can be seen in a case study from Hesse. In 1960, the "Hessian Working Group for Health Education" (Hessische Arbeitsgemeinschaft für Gesundheitserziehung - HAGE) was founded in Marburg. It was co-financed by Behringwerke and therefore, focused primarily on vaccination education (Hartung, 1963). The most important aim of the HAGE was to expand vaccination education within schools. When the oral polio vaccination was introduced in the 1960s (Lindner, 2004), schools were almost overwhelmed with advertising. Brochures containing a "Health quiz about polio" with a circulation of 300,000 copies were distributed to school classes. ${ }^{5}$ Now vaccination education was extended to include small children. With balloons, craft sheets and pencils, the HAGE message "Vaccination protection today - safety tomorrow" also reached primary schools. School radio became an important medium for vaccination education too; radio plays such as "Emil von Behring, Fighter against Diphtheria" staged the discovery of the diphtheria vaccination as a crime play suitable for school-aged children: "Yes, Behring hated it, this epidemic, just as one hates a murderer, and he wanted to pursue it and render it harmless". ${ }^{6}$

From today's perspective, vaccination education in schools is regarded as an anxious, often even naïve approach. However, letters to parents, radio plays, messages on balloons or quizzes in picture books, mark a turning point from the intervention state, which for a long time ensured compulsory vaccination programmes with the help of compulsory schooling. In this respect, vaccination education constituted a fundamental development of the 20th century: the normalization of immunity. As a result of decades of vaccination education, immunity became commonplace and characterized the general outlook on life. Voluntariness, persuasion and advertising for vaccination programmes were of course the strategies of politicians, medical officials and pharmaceutical companies. However, vaccination education translated the topic of vaccination into simple images and messages, thus increasing the compatibility of vaccination programmes with everyday life.

The change in educational concepts - from a dutiful subject to a solidary and foresighted citizen - changed the concept of vaccination and vice versa: the success of new vaccination programmes promoted the implementation of vaccination education. Thus, physicians made an astonishing discovery at the beginning of the 1940s. While compulsory vaccination against smallpox resulted in an average vaccination rate of between 70 and $80 \%$, the vaccination rate for the voluntary diphtheria vaccination was between 93 and $99 \%$, as Walter Bieber of the Ministry of the Interior pointed out in 1940. Since propaganda had succeeded in ensuring that "up to $99 \%$ of the children [...] attended vaccination appointments", compulsory measures were absolutely unnecessary, as the report ended reassuringly: "why use coercion if people attend voluntarily?" (Bieber, 1940/41, p. 69) Voluntariness and vaccination education were, therefore, not the result of the liberalization of public health, certainly not in the "Third Reich". Appeals focusing on self-care and solidarity simply seemed to be more effective than coercive measures.

\section{References}

Aumiller, J. (1970). Werbung in der Medizin. Unter besonderer Berücksichtigung der Impfkampagnen gegen die Poliomyelitis. München.

Behringwerke (1941). Organisation und Technik der Diphtherieschutzimpfung. Erfahrungen und Anregungen. I. G. Farbenindustrie Aktiengesellschaft Leverkusen.

Beratung einer beabsichtigten reichsgesetzlichen Aenderung des Impfgesetzes vom 8. April 1874 durch Einfügung einer Gewissensklausel nach englischem Muster. Bericht über die Verhandlungen eines Unterausschusses des Ausschusses c für die Seuchenbekämpfung vom 21. Februar 1934. (1934). Berlin.

Bieber, W. (1940/41). Seuchenbekämpfung im Kriege. Der Öffentliche Gesundheitsdienst, 6, 65-70.

Colgrove, J. K. (2006). The state of immunity. The politics of vaccination in twentieth-century America. University of California Press.

Deutscher Reichstag (1874, Februar 18). Reichstagsprotokolle. Bayerische Staatsbibliothek.

Deutscher Reichstag (1896, Mai 08). Reichstagsprotokolle. Bayerische Staatsbibliothek.

Durbach, N. (2005). Bodily matters. The anti-vaccination movement in England, 1853-1907. Duke University Press. 
Gundel, M. (1936). Die aktive Schutzimpfung gegen Diphtherie und die Ergebnisse der in den Jahren 1934 und 1935 in Deutschlands durchgeführten Diphtherieschutzimpfungen. Im Auftrage des Reichs- und Preuß. Ministerium des Innern durchgeführt und bearbeitet von Max Gundel. Berlin.

Hartung, K. (1963). Schutzimpfung und Gesundheitserziehung. Frankfurt am Main.

Huerkamp, C. (1985). The history of smallpox vaccination in Germany: A first step in the medicalization of the general public. Journal of Contemporary History, 20(4), 617-635. https://doi.org/10.1177/002200948502000407

Hüntelmann, A. C. (2011). Pharmaceutical markets in the German empire. Profits between risk, altruism and regulation. Historical Social Research (HSR), 36(3), 182-201. https://doi.org/10.12759/hsr.36.2011.3.182-201

Laurenz Sonderegger, J. (1930). Gesundheit ist Lebensglück. Gedanken des Volksgesundheitslehrers Dr. Jakob Laurenz Sonderegger für Schule und Haus (C. Adam \& F. Lorentz, Eds.). Springer. https://doi.org/10.1007/978-3-66242988-4

Lengwiler, M., \& Madarász, J. (2010). Präventionsgeschichte als Kulturgeschichte der Gesundheitspolitik. In M. Lengwiler \& J. Madarász (Eds.), Das präventive Selbst. Eine Kulturgeschichte moderner Gesundheitspolitik (pp. 11-28). Transcript. https://doi.org/10.14361/transcript.9783839414545.11

Lindner, U. (2004). Gesundheitspolitik in der Nachkriegszeit. Großbritannien und die Bundesrepublik Deutschland im Vergleich. De Gruyter. https://doi.org/10.1524/9783486707588

Thießen, M. (2017). Immunisierte Gesellschaft. Impfen in Deutschland im 19. und 20. Jahrhundert. Vandenhoeck \& Ruprecht.

Sauerteig, L. (1995). Moralismus versus Pragmatismus: Die Kontroverse um Schutzmittel gegen Geschlechtskrankheiten zu Beginn des 20. Jahrhunderts im deutsch-englischen Vergleich. In M. Dinges \& T. Schlich (Eds.), Neue Wege in der Seuchengeschichte (pp. 207-247). Franz Steiner.

Tolley, K. (2019). School vaccination wars: The rise of anti-science in the American anti-vaccination societies, $1879-1929$. History of Education Quarterly, 59(2), 161-194. https://doi.org/10.1017/heq.2019.3

Walloch, K. L. (2007). “A hot bed of the anti-vaccine heresy”. Opposition to compulsory vaccination in Boston and Cambridge, 1890-1905. [Doctoral Dissertation, University of Wisconsin-Madison].

Woollacott, M. (1998). The politics of prevention. In J. Franklin (Ed.), The politics of risk society (pp. 120-123). Polity Press.

\section{Recommended Citation}

Thießen, M. (2020). Learning for life: From compulsory vaccination to vaccination education in 19th and 20th century Germany. On Education. Journal for Research and Debate, 3(8). https://doi.org/10.17899/on_ed.2020.8.1

About the Author

Malte Thießen is head of the LWL-Institut für westfälische Regionalgeschichte in Münster, Germany. His research interests range across the history of vaccination and health in Germany and Europe, regional topographies of national socialism, the history of digital transformation, oral history, and cultures of memory.

\footnotetext{
${ }^{1}$ Bundesarchiv Berlin, R 86/4704, Report of Prussian Deputation for Medicines, 23/11/1904.

${ }^{2}$ Staatsarchiv Hamburg, 361-2 V/909a vol. 2, letter from the police deputation to the school deputation, 09/05/1928.

${ }^{3}$ Stadtarchiv Frankfurt, Schulamt/7098, Excerpt from a decree of the Ministry of the Interior, 20/03/1936.

${ }^{4}$ Staatsarchiv Niedersachsen, Rep. 630, 242-4/892, Brochure of Farbenwerke Bayer/Behringwerke, 1952.

${ }^{5}$ FAZ, Plakate propagieren den Impfcocktail, 19/04/1962.

${ }^{6}$ Behringarchiv Marburg, 09-15/1608, Manuscript of the WDR (Westdeutscher Rundfunk), 26/01/1957.
} 